Karadeniz Uluslararası Bilimsel Dergi

Volume: 51, Autumn-2021, p. (210-219)

ISSN: 1308-6200 DOI Number: https://doi.org/10.17498/kdeniz.977855

Research Article

Received: July 2, 2021 | Accepted: Sep 16, 2021

This article has been checked for plagiarism.

\title{
THE ROLE OF DISCUSSION IN ACTIVE TEACHING AND DIALOGUE CULTURE BUILDING
}

\author{
AKTİF ÖĞRETIMDE VE DIYALOG KÜLTÜRÜ BECERISIININ \\ OLUŞUMUNDA TARTIŞMANIN ROLÜ
}

\section{РОЛЬ ДИСКУССИИ В АКТИВНОМ ПРЕПОДАВАНИИ И СОЗДАНИИ КУЛЬТУРЫ ДИАЛОГА}

\author{
Nodar MIRAZANASHVILI* \\ Manana MICHITASHVILI**
}

\begin{abstract}
The objective of the paper is an active application of the discussion method in the process of teaching the social sciences, with the focus on the subject of history that develops creative thinking, the intellectual and analytical capacity of students. The paper brings in focus the importance of using class discussion in active teaching since this method activates and maximally engages students in learning process. In the process of discussion, students develop their logical, critical and creative thinking, cognition as well as personal responsibility. The discussion stimulates an ability to substantiate the position or idea through healthy argument and judgment. It also supports the formation of democratic values among the students. It also encourages tolerance and understanding of opposite ideas. The discussion increases self-esteem and allows self-assertion. Application of discussion improves the ability of the students to conduct dialogue, express their ideas freely, provide argumentation in support of their position, cooperate, communicate, regulate conflict situations in interaction with peers and achieve consensus without confrontation.

Alongside the range of discussion forms, the objectives of the discussion method are also considered in the paper. The paper describes a comprehensive process of selection of the discussion topics, the question types used during the discussion as well as the procedures of leading the discussion. The role of a teacher to create a trustful, respectful, and healthy environment for the class discussion is well explained. In addition, the active and thematic planning of the discussion method in teaching different topics of History is comprehensively covered in the paper.
\end{abstract}

"ORCID: 0000-0003-0123-2762, Associate Professor of Gori State Teaching University, 53 Ilia Chavchavadze Street, Email: nmirazanashvili@gmail.com

** ORCID: 0000-0003-3718-9073, Associate Professor of Gori State Teaching University, 53 Ilia Chavchavadze Street, Email: mananamichitashvili@gmail.com 


\section{Nodar MIRAZANASHVILI - Manana MICHITASHVILI}

Keywords: effective method of discussion, building dialogue of culture, teaching history via discussion method, open and closed questions in discussion, skills obtained by learners through discussion

\section{ÖZ}

Makalede, tarih konularına odaklandıklarında öğrencilerin: yaratıcı düşünme, düşünsel ve analitik yeteneklerini geliştiren sosyal bilimler öğretiminde kullanılan tartışma yöntemleri tetkik edilmiştir. Kullanılan yöntemlerin öğrenim sürecinde öğrenci katılımını etkilediğinden ve kalitesini artırdığından dolayı, aktif öğretimde konu üzerine sınıftaki tartışmaların önemine dikkat çekilmiştir.

Tartışma sırasında öğrencilerin mantıksal, eleştirisel, yaratıcı düşünme, bilgi ve kişisel sorumluluk yetenekleri gelişmektedir. Tartışma metodu mantıklı argümanlar ile yaklaşımlara dayalı olan bir tutumun öğrencilerde savunma yeteneklerini uyandırır. Tartışma aynı zamanda saygı ve karşıt fikirleri hoşgörü ile kabul etme davranışlarını da teşvik eder. Tartışma öğrencilerde özgüveni artırır, kendilerini ispatlamaya yol açar ve bununla birlikte öğrencilerde demokratik değerlere karşı saygı göstermeleri bilinci oluşturur. Tartışma metodu öğrencilerin diyaloga girme becerilerini geliştirir, fikirlerini özgürce ifade edebilme duygusunu geliştirir, kendi tutumlarını savunmakta, arkadaşlarıyla iş birliği yapmakta, iletişim kurmakta, gergin durumları düzenlemekte ve fikir birliğine varmakta yardımcı olur.

Makalede, tartışma biçimlerinin çeşitliliği yanı sıra tartışma yöntemlerini de ele alınmıştır. Burada tartışma konularının seçim süreci, tartışma sırasında kullanılan soru türleri ve tartışmayı yürütme yöntemleri, sınıftaki tartışma süresinde güvenilir, karş1lıklı saygı ve sağlıklı bir ortam yaratmada öğretmenin rolü irdelenmiştir. Ayrıca makalede tarihin çeşitli konularını açıklarken tartışma yönteminin aktif ve tematik planlaması üzerine kapsamlı bir şekilde durulmuştur.

Anahtar Sözcükler: etkili tartışma yöntemi, kültür diyaloğu oluşturma, tartışma yöntemiyle tarih öğretimi, tartışmada açık ve kapalı sorular, öğrencilerin tartışma yoluyla edindiği beceriler.

\section{АННОТАЦИЯ}

Целью статьи является активное применение дискуссионного метода в процессе преподавания общественных наук с акцентом на предмет истории, который развивает творческое мышление, интеллектуальные и аналитические способности студентов. В статье подчеркивается важность использования обсуждения в классе при активном обучении, поскольку этот метод активирует и максимально вовлекает учащихся в учебный процесс. В процессе обсуждения студенты развивают логическое, критическое и творческое мышление, познание, а также личную ответственность. Обсуждение стимулирует способность обосновать позицию или идею с помощью здоровых аргументов и суждений. Обсуждение также способствует терпимости и пониманию противоположных идей. Обсуждение повышает самооценку и позволяет самоутверждению. Оно также поддерживает формирование у студентов демократических ценностей. Применение обсуждения улучшает способность студентов вести диалог, свободно выражать свои идеи, аргументировать свою позицию, сотрудничать, общаться, регулировать конфликтные ситуации во взаимодействии со сверстниками и достигать консенсуса без конфронтации. Наряду с разнообразием форм обсуждения в статье рассматриваются также задачи метода обсуждения. В статье описывается комплексный процесс выбора темы для обсуждения, типы вопросов, используемые во время обсуждения, а также процедуры 


\section{The Role Of Discussion In Active Teaching And Dialogue Culture Building}

ведения обсуждения. Хорошо объяснена роль учителя в создании доверительной, уважительной и здоровой атмосферы для обсуждения в классе. Кроме того, в статье всесторонне освещаются активное и тематическое планирование дискуссионного метода при преподавании различных тем истории. Ключевые слова: эффективный метод обсуждения, построение культуры диалога.

Ключевые слова: эффективный метод обсуждения, построение культури диалога, преподавание истории через метод обсуждения, открытые и закрытые вопросы в обсуждении, навыки, полученные студентами в ходе обсуждения

\section{Introduction}

The 21 century puts teachers to face new challenges. A desire to improve the quality of education becomes more vivid. The priorities of active teaching at the classes have been identified that include discussion (Lat. „discussio“examination, discussion, judgment). Discussion means disputation of different positions and ideas verbally or through the presentation, it can be rarely expressed in written form. It is one of the most effective methods of interactive teaching. The aim of this method is to discuss a certain opinion, idea, or problem in a group and freely exchange points of view. This method activates and maximally engages students. The discussion stimulates an ability of substantiation of the position or idea through healthy argument and judgment. It also encourages tolerance and understanding of opposite ideas. The discussion increases self-esteem and allows self-assertion. It improves the ability of students to cooperate, communicate, regulate conflict situations, interact with peers and achieve consensus.

In the process of discussion, students develop their logical, critical and creative thinking, cognition as well as personal responsibility. They also learn how to protect their position through argumentation and learn to respect the opposite ideas. The discussion gives optimal possibility to the learners to comprehend their spiritual world since a teacher creates respective atmosphere through pedagogic work where a student is represented with his/her true spiritual beliefs.

\section{Methods}

Using discussion as a teaching method enables us to see alternative ways of solving a problem. There are diverse options in positioning and argumentation that might lead to different conclusions and evaluations. The method of discussion allows an exchange of ideas, views, and assertions for the identification of truth (Postman, 2007: 67).

The discussion is based on dialogue. Dialogue is an effective way of managing conflict situations while opposing different ideas. Achieving a consensus is possible only through dialogue that excludes confrontation. Culture of dialogue helps students to improve cooperation, communication and to easily overcome a fear of public criticism or defeat. It also supports the formation of democratic values among the students.

Socrates, an ancient Greek philosopher, is the founder of dialogue. The method of Socrates considers the inclusion of problematic questions rather than informative ones in the dialogue. He requests judgment from the learners to be able 


\section{Nodar MIRAZANASHVILI - Manana MICHITASHVILI}

to solve the problem independently. Socrates outlines two steps of gaining knowledge: inductive reasoning and discovery of general definition for pursuing "idea of unattainable knowledge". Socrates' dialogue does not aim to identify the winner in the dispute. It is a quest for the truth. Professor D. R. Swanson offers an interesting opinion on how to prepare for Socrates' dialogue which allows expressing individual interpretation and personal positions throughout the dynamics of learning processes (Swanson, 2009: 49-50).

\section{Discussion}

The discussion is especially productive when it is related to the topic already studied or the material that is not yet fully covered but the students already have enough information after teacher's informative presentation to solve the discussion issue. While selecting the topic of discussion for the class a teacher should identify the issue that will foster the development of the different opinions. This will enable students to present their opinions providing the arguments that serve as evidence and teach them to tolerantly listen and understand the various ideas on the topic (Institute of Civil Development 2012: 88).

It is essential that students have certain information about the discussion issue in order to be able to present their ideas, position, and arguments as well as to protected alternative ideas, objectively assess others' thoughts. Otherwise, the discussion will lose its importance and students- their motivation.

For effective discussion, the teacher should consider the following factors: preparation of the students, rules and procedures, management of discussion, and excepted results. The enabling environment should be created during the class discussion for the students to freely exchange opinions; express the new ideas; listen and comprehend others' ideas; analyze the issue deeply and in detail, and improve communication and self-expression skills. Thus, the teacher should select the respective form of teaching that will create the proper environment and simplify the communication.

The important preparatory activities should be preceded prior to starting the discussion. If the different discussion methods are applied the proper instruction should be given to students about the discussion rules. It should be made impermissible to disregard the different ideas or disrespect a person presenting them. The focus should be brought to discussing different positions and not the authors of these positions. The time limit of each presenter should be jointly defined actively engaging all participants. Having the discussion completed, the results should be summarized and assessed. In regards to assessment criteria, it should be prepared in advance jointly by the teacher and students. The specific objectives and areas should be focused on to make the discussion effective (National Assessment and Examination Center, 2010:66).

As mentioned, prior to starting the discussion, the format should be defined: what are the opening questions; what the main issue of discussion is; what can be arguments or counter-arguments of the parties; what the sequence of the discussion is. The most important is to rightly define the objective that the 


\section{The Role Of Discussion In Active Teaching And Dialogue Culture Building}

discussion will achieve. The discussion starts with the main question that determines discussion flow, sets optimal conditions, and creates a learning environment. The teacher remains a neutral party not expressing personal sympathy or antipathy. Through verbal encouragement to express the opposite ideas, a teacher creates a trustful and respectful atmosphere in the class. An approach of a teacher towards students usually determines students' relations with their teacher. A teacher should preserve herself/himself from differentiating groups as well as the ideas expressed by the involved parties. If a teacher's position on the given topic is different from those expressed by the discussion participants, the position should be enriched with strong arguments to show that this position has a right to exist. Deviation from the discussion topic or disputing the secondary issues that are not principle for the topic should be avoided. It should be mentioned that there can be groups that do not have any positions. In such a case, the group selects the position during the discussion and tries to provide argumentation for their choice.

"The group of experts" composed by the students is also involved in the working process. The group actively participates in the analysis and assessment of the final results. In the end, the leader of the discussion generates and makes conclusions. If a special interest is observed in the discussion, further research on the topic can be offered like the preparation of a thesis or a project.

Thus, the following objectives of the discussion are important:

To engage the students in the class processes and enable them to express their ideas freely;

To clarify to the students that there is no wrong or correct ideas but there are the ideas supported by evidence;

To analyze all positions;

To increase self-esteem and self-affirmation among the students;

To develop communication skills of the students;

To present the alternative ways of solving the discussion issue;

To enable students to consider the others' ideas and develop in them consensus achieving skills;

To capacitate students to have argumentation for their positions as well as to draw conclusions;

To clarify that the participants can change their position in the process of discussion;

To clarify the understanding of discussion topic by the students;

To objectively summarize and assess the discussion results.

The role of a teacher in the process of discussion is essential; some key points are enlisted below:

The teacher explains the purpose of the lesson;

The teacher facilitates the discussion and is not involved in the content of discussion;

The teacher supports students to be actively engaged in the discussion;

The teacher enables students to freely express their opinions; 


\section{Nodar MIRAZANASHVILI - Manana MICHITASHVILI}

The teacher controls the situation and ensures that the students follow the set rules, listen to each other and neither divert from the discussion topic nor incline towards personal offense;

The teacher encourages to objectively assess the arguments and validity of the position;

The teacher ensures that the students come to the solution of the discussion issue independently based on the voiced arguments and evidence.

The method of discussion, like other methods, has its strength and weaknesses. The strength of this method is as enlisted below:

The issues analyzed during the discussion deeply stay in the memory;

The discussion in the best method for development of critical and creative thinking in the students;

The discussion method enables students to work independently to search for the trustful evidence for proving their position;

The discussion increases students' engagement and teaches how to create a personal position on the topic; how to present or protect the position;

The discussion method enhances theoretical knowledge;

The discussion improves the communication and collaboration skills of the students;

As a weakness of the discussion can be considered the points that follow:

The discussion might be followed by a conflict, expression of strong emotions however, it can be used to improve learning or research skills;

Sometimes a student has to disagree with the ideas expressed publicly, which is difficult for some. While conducting disputes, students cannot often sufficiently assess the opposite idea;

There is certain fear among the participants that others might not like his/her idea and might be publicly criticized for expressing the opposite idea or decision;

In a limited time, it is not often possible to discuss all the aspects of the discussion topic;

There are quantitative limitations;

If discussion is not sufficiently planned it might take long and fail to achieve desired results.

The students' motivation, as well as the discussion results, are mostly determined by the discussion questions. The slogan of the discussion - the one, giving the questions, rules - support this assumption. While planning discussion a combination of open and closed questions should be used. The paraphrases or additional specific questions can be applied to make the statement clearer. The closed questions can be used for the engagement of the learners with special needs. In addition, silent or shy students can be engaged in the discussion through these types of questions, plus giving additional specific tasks. The students who do not allow others to express their ideas need special attention too. In individual situations sometimes, a student possesses information but is not able to make an effective decision where the closed questions help. This type of question is also 


\section{The Role Of Discussion In Active Teaching And Dialogue Culture Building}

useful when the discussion is ending but the conclusions have not been yet made.

The open questions are different from the closed questions. These are questions that cannot be answered with just 'yes' or 'no'. The open questions can de be divided into several groups that are as follow: hypothetic, cognitive, encouraging, stimulating, investigative, summarizing. These are the questions of the utmost importance for leading the discussion that belongs to a high level of cognition. Answering open questions requires certain knowledge, judgment, intelligence, and cognitive skills from students. Thus, it means that a student has the knowledge, is capable to comprehend the question, establish links and answer it using his/her knowledge about the issue and providing suppositions, evidence, and conclusions.

\section{Results}

Although the discussion, as a method of teaching, is widely used in classes of social sciences, the most productive is to apply this method in teaching of History. Any topic, though being controversial enough, can be used the discussion. The topic should provoke controversy to debate and discuss the opposing opinions. It should allow diverse ways of comprehension and argumentation also considering the availability of the respective evidence. In addition, it should allow constructing and proving hypothesis that reflects a respective motivation while considering the historic facts. The topic of discussion should also allow interpretation and alternative ways of solving a problem; the latter can be achieved through logical conclusions. The topic can be a historic fact or persons, the historic sources or documents allowing interpretation.

The discussion can be organized in different forms. As widely known, the pedagogical practice recognizes the following forms of class discussion: round table, panel discussion, forum, symposium, debates, and trial. All the forms of the discussion are the best means of gaining knowledge; performing an in-depth analysis of historical material, and promoting free judgment and argumentation.

It is recommended to use an effective method for the group work called "choose a position" prior to conducting the discussion with learners of the elementary and basic steps. During this activity, the learners are grouped according to the express positions. It is good to use "Agree", "Disagree", and "Not sure" posters on the walls of the class. As the learners have the final position (they have a right to stay in their initial position) towards the issue, they work for the additional arguments to protect their position in the process of discussion. This activity is useful to incite different positions as well as to teach time management. This is especially effective if it follows a teacher's presentation on the same lesson. The teacher can give a student a preceding task in line with the students' position. This task might include finding information from different types of sources; application of education resources that will easily show those students who changed the position about the issue.

It has proved to be the most fruitful to apply the discussion method with the 12th-grade students while covering the topic of "The Berlin Wall and its 


\section{Nodar MIRAZANASHVILI - Manana MICHITASHVILI}

parallels in Georgia" under the lesson" The divided Europe". The teacher shows the presentation and tells the students about the Berlin Wall history, the role of Hans-Dietrich Genscher in the reunification of Germany. The students listen to the public address of Genscher to the people of Germany, they watch the reunification ceremony and learn about the approaches of world leaders towards this fact. Thus, the students listen and watch the video material depicting the politically important events and in parallel receive additional information. The presentation finishes with the issues related to the annexation of Georgian territories. The issues like the fall of Berlin Wall, unification of Germany, John Kennedy's remarks in Berlin, and the cite from there "an offense not only against history but an offense against humanity" are distributed within the groups (Kennedy, 1963). The students clarify whether this quotation from Kennedy's remark is relevant to Georgian reality, the latter having the occupied territories. The discussion is the best way to draw the parallels between the historic events, find the respective information in the primary sources, provide trustful answers to the questions and make conclusions.

David Perkins's assumption that understanding does not follow knowledge but it precedes knowledge- needs to be taken into consideration (Perkins 2007:222223). The obtained functional, transfer knowledge enables a student to apply it adroitly in the Georgian context via knowledge transfer that is based on casual connections. The students probe deep into objective reality, they study the hardship of the Georgian population living near the borderline since the RussianGeorgian war in August 2008; recurrent cases of human rights violation; creeping annexation of Georgian territories; the role of the international organizations and world community to end human rights violations in borderline regions of Georgia. In addition, the groups of students explore exhibited material depicting the construction of the Berlin Wall-like in front of the Stalin Monument located in the center of the town of Gori (Georgia). Furthermore, the students study video, audio, and photo material of media reporters illustrating creeping annexation. They listen to records of people who experienced the August 2008 war and descriptions of the lost territories and the hardships of people living at the borderline as well as vandalism of cultural heritages. At the end of the discussion, they dispute about the ways of solving this situation peacefully. The discussion finishes by presenting an electronic album that will be sent to the international organizations operating in Georgia in order to remind about the ongoing creeping annexation of Georgia by Russia.

Furthermore, the problem raised by each group can be divided into separate parts - so-called problem components- to enable the groups to present their position in an original and more comprehensive way based on the argumentation. During the preparatory period, students are guided to find the needed historical information and effective presentation material including respective education resources (maps, primary and secondary sources, genealogical tables, battle schemes, video-audio material) to prove the selected position. Alternatively, the students can create the resources/ products themselves that will provide them the basic information to 


\section{The Role Of Discussion In Active Teaching And Dialogue Culture Building}

construct their position and its argumentation. The students get more motivated and active if topics are related to identification of guiltiness or merits of the historical figures; establishing connections between historic facts and events. Moreover, the students should be given the freedom to seek alternative ways and make their own authentic discoveries to protect their position. They should be encouraged to present how their position might change historical processes and how the country could benefit from their disputed position.

As also stipulated in the National Curriculum of Georgia, the discussion can be planed thematically: a) Discussions to assess whether the correct decisions were made and whether the alternative ways existed. The decision-making process will help students to investigate the hypothetic situations, describe the taken decision as well as alternative variations of this decision with supportive arguments and evidence. Under this thematic area, the students could work to identify, correctness of the decision of the King court, the long, obstinate, unpromising battles with world conqueror Timur the Lame or the alternative way of reconciliation; a decision of the King Gubaz of the Egrisi Kingdom to oppose Byzantines via Persians, etc (National Center for Teachers' Professional Development, 2009:140); b) Discussions that focus to assess the kings, military leaders and public figures; c) Discussions that focus to explain the causal connections of political processes and search for the right decisions. As an example for this thematic area could serve work on the results of the battles of Napoleon Bonaparte, the results of Russia ruling in Georgia, the national movement for independence, etc; d) Discussions that focus on identification of the ways to overcome the domestic challenges and external political conflicts. For example, the following open questions can be used 'How it was possible to determine in advance expected results or find the alternative ways of the battles at Maranda, Garnisi, and Krtsanisi?

While covering the lessons "Georgia and Caucasus under the interest of world politics" with the 12th-grade students, it will be effective to use the discussion method to dispute the following issues: 'What was the interest of the European countries forwards the Caucasus after the First World War?'; 'What was the interest of the USA towards Georgia?'; 'Why Georgia could not become a member of the League of Nations?',

Thus, the class discussions help to increase the multiple abilities of the students to understand and analyze, to express their individuality and personal positions and initiatives in the dynamics of learning processes, to make free interpretations, and enjoy a trustful environment created in the class. The discussion method increases students' engagement while working on the historical sources. The different historical sources prove the same fact; however, those might fulfill the gaps that hinder a comprehensive understanding of the event. From this perspective, it is interesting to apply this method while teaching lives of the kings, historical persons, chroniclers, bibliography of well-known persons or travelers, historical papers, important government documents, etc. that give trustworthy information to strengthen a different position and constructively lead a dialogue. 
To conclude, critical and creative thinking, which is the key objective of education, is essential in active teaching to shape a personality, hence, the class discussion plays a crucial role in this.

\section{REFERENCES}

Postman, N., (2007). "Ganatlebis mizani”, Tbilisi

Swanson, D.R., (2009). "Stsavlebis metodologiis sakhelmdzgvanelo", Tbilisi

Institute of Civil Development, (2012). "Critikuli da shemokmedebiti azrovneba, tsarmosakhviti ganaTleba", Tbilisi

National Assessment and Examination Center, (2010). "Efektiani stsavleba, teoria da praqtika", Tbilisi

Kennedy, J. F., (1963). https://www.jfklibrary.org/archives/other-resources/john-fkennedy-speeches/berlin-w-germany-rudolph-wilde-platz-19630626

Perkins, D., (2007)." Smart Schools Better Thinking and Learning for Every Child National Center for Teachers' Professional Development, (2009). "Efeqturi swavleba skolaSi”, Tbilisi 